\title{
TCF3 Fusion Partner
}

National Cancer Institute

\section{Source}

National Cancer Institute. TCF3 Fusion Partner. NCI Thesaurus. Code C97839.

TCF3 fusion partner (253 aa, $28 \mathrm{kDa}$ ) is encoded by the human TFPT gene. This protein plays a role in the promotion of apoptosis. 